\title{
Relating Stress, Anxiety and Depression among Flood Victims'Quality of Life in Malaysia: A Theoretical Perspective
}

\author{
Johana Johari and Najib Ahmad Marzuki
}

\begin{abstract}
Flood disaster is one of the events that have an impact on the lives of the individuals involved in Malaysia. Destruction and loss make a person feels depressed besides being worried. Even worse when the victims become depressed as a result of the incident. Flood events can be seen as a threat to the well-being of individuals both physically and emotionally. This article will discuss how stress, anxiety and depression are relatedtothe quality of life and well-being of flood victims. The discussion is based on the Stressful Life EventsTheory, Freud's Anxiety Theory, Beck's Cognitive Theory of Depression and the Quality of Life Conceptual Model.
\end{abstract}

Index Terms-Flood, stress life events, freudanxiety theory, beck cognitive theory of depression, conceptual model quality of life.

\section{INTRODUCTION}

Flooding in Malaysia has various impacts on the affected population in terms of damage to property, destruction of property and loss of life. In general, the average rainfall for all the states in Malaysia is 2,500 $\mathrm{mm}$ a year [1]. This has put Malaysia as one of the countries with the heaviest rainfall in the world. Flood disaster has created sufferings, pain and agony among the victims.

In relation to this, stress and anxiety have been recognized as factors that could lead to depression and this will affect the quality of life of those involved. With the growing number of victims each year, much needs to be done in order to ensure quality health and well-being. Victims are regularly plagued by flooding that has happened before. This gives rise to stress and anxiety among flood victims. Residents expressed concern and pressure on natural eventsaftera long period of heavy rain. As a consequence, their daily lives are always in a state of alert. Hence, they are worried of repeated flooding [2].

With a total number of 189 river systems $(1,800$ small rivers altogether) spanning across 57,300 kilometres, many low terrain areas are affected by serious flooding. In general, flood can be categorised under three categories, namely flash flood, monsoon flood and tropical flood. However, in Malaysia, the most suffered flood is the monsoon flood caused by the effect of continent location and sea water level[3]. Areas that are affected by serious flooding span across 29,800 kilometres, which is about 9 percent of the total

Manuscript received May 25, 2013; revised August 1, 2013. This work was supported in part by the Ministry of Higher Education Malaysia under the Long-Term Research Grant Scheme (LRGS/b-u/2012/UUM/Communication Technology and Information).

Johana Johariand Najib Ahmad Marzuki arewith the School of Social Development, Universiti Utara Malaysia, 06010 Sintok, Kedah, Malaysia. (e-mail: jjohana9@yahoo.com; najib320@uum.edu.my). area in Malaysia. Monsoon flood normally affects the states of Johor, Terengganu, Pahang, Sabah dan Sarawak. Nevertheless, other states such as Perlis, Kedah, Pulau Pinang, Perak, Selangor, Negeri Sembilan, Melaka and Wilayah Persekutuan Kuala Lumpur did experience flash floods[1]. Even worse, in 2010, these flash floodshave turned into a nightmare when it became a natural disaster and affected areas that had never suffered flooding before. The total number of flood victims can be seen in Table I [4].

TABLE I: TOTAL NUMBER OF VICTIMS

\begin{tabular}{|l|l|l|l|l|}
\hline State & $\begin{array}{l}\text { Number } \\
\text { of relief } \\
\text { centres }\end{array}$ & $\begin{array}{l}\text { Number } \\
\text { of } \\
\text { families }\end{array}$ & $\begin{array}{l}\text { Number } \\
\text { of } \\
\text { victims }\end{array}$ & $\begin{array}{l}\text { Death } \\
\text { Cases }\end{array}$ \\
\hline Perlis & 57 & 2,921 & 15,261 & 0 \\
\hline Kedah & 202 & 15,257 & 64,924 & 6 \\
\hline Kelantan & 45 & 1,622 & 5,311 & 3 \\
\hline Terengganu & 84 & 1,499 & 6,061 & 0 \\
\hline Johor & 376 & 30,276 & 116,660 & 6 \\
\hline Melaka & 32 & 2,325 & 9,089 & 1 \\
\hline Negeri Sembilan & 27 & 715 & 3,083 & 0 \\
\hline Pahang & 45 & 961 & 4,650 & 0 \\
\hline Sabah & 20 & 903 & 3,389 & 5 \\
\hline Sarawak & 18 & 615 & 2,949 & 0 \\
\hline Total & 906 & 57,094 & 231,377 & 21 \\
\hline Source: National Secul & & & \\
\hline
\end{tabular}

Source: National Security Council, 2011

Effects suffered by each victim in Malaysia are different depending on the experiences during the flood. Victims are still faced with the risk of flooding in the future. The question arises in terms of the feelings experienced by the victims is do they suffer from stress, anxiety and depression when thinking about the recurrent risks? Any daily activities arecertainly affected if the unforeseen incident occurs again. The psychological and physiological effects and change will be experienced by those who are dealing with stress [5].

When a person is faced with stress and anxiety, their quality of life will be affected.According to Ferran[6],one's well-being or quality of life is geared towards how a person can live a normal and quiet life, capabilitiesto lead to a more meaningful social life, joy and satisfaction, and achieve physical and mental ability.

Based on the above discussion, the objective of this paper is to discuss the possible theoretical perspective via model integration for the purpose of conducting a research on flood management relief.

\section{Conceptual Definition}

\section{A. Stress, Anxiety and Depression}

Selye (1968) mentioned that the stress tradition encompasses a diffuse and multifaceted array of psychic, 
somatic, and interpersonal problems that often arise as responses to the strains of everyday life. There is eustress when it helps us perform better, or distress when it causes upset or makes us sick. The causes of stress are called stressors or triggers [7].

The anxiety disorders represent a failure to either elect an adaptive response or to inhibit a maladaptive response given a situation. Anxiety is a state of diffuse arousal following the perception of a real or imagined threat. This fundamentally experiential, future-oriented, self-focusing emotion at times can be adaptive, as anticipatory problem-solving thoughts are triggered. Anxiety disorders will directly implicates emotion [8], [9].

Depression is not the same as a blue mood, which is a normal short-term experience of sadness or loss. Depression is an illness that involves the body, mood, and thoughts. Often referred to as the invisible disease, it affects the way a person eats and sleeps, the way one feels about oneself, and the way one thinks about things. Depression is not a sign of weakness or a condition that can be willed or wished away. People who are depressed cannot merely "pull themselves together" and get better. Without treatment, symptoms can last for weeks, months, or years. Appropriate treatment, however, can help most people who suffer from depression [10], [11].

TABLE II: SCALE AND FEATURES OF DEPRESSION,ANXIETY AND STRESS

\begin{tabular}{|c|c|}
\hline Scale & Features \\
\hline Depression & $\begin{array}{l}\text { Chide } \\
\text { Frustrated, moody, blue } \\
\text { Convinced that life has no meaning and } \\
\text { worth } \\
\text { Pessimistic about the future } \\
\text { Do not get the pleasure or satisfaction } \\
\text { Not interested in engaging in any activity } \\
\text { Less initiative }\end{array}$ \\
\hline Anxiety & $\begin{array}{l}\text { Worry, panic } \\
\text { Shy, not confident } \\
\text { Sweating, dry mouth, shortness of } \\
\text { breath, heart palpitations, sweatiness of the } \\
\text { palms } \\
\text { Worried about performance, the possibility of } \\
\text { losing control }\end{array}$ \\
\hline Stress & $\begin{array}{l}\text { Over-aroused, tense } \\
\text { Unable to relax } \\
\text { Sensitive, irritable } \\
\text { Easily startled } \\
\text { Worried, agitated, restless } \\
\text { Tolerance interrupted or otherwise } \\
\text { affected }\end{array}$ \\
\hline
\end{tabular}

In this paper definitionsof depression, anxiety and stress are based on the Depression Anxiety Stress Scale (DASS) by Lovibond and Lovibond [12]. It has been noticed that stress makes the person easily offended, becomes angry, loses focus on the job and this will have an impact on one's health. Concerns about uneasyfeelingsareusually responded as nervous, scared and worried about the effects of psychological factors, while depression is a disturbance resulting in the loss of a sense of happiness and excitement about things around. This reaction is caused by a condition or event that causes a person to feel loss in terms of economic factor, family, health and social services. The salient features of the scale are as Table II.

\section{B. Quality of Life}

Quality of life is a broad concept that incorporates all aspects of life and has been used in a variety of disciplines such as geography, philosophy, medical sciences, social sciences, health promotion and advertising [13].

Many factors such as physical, spiritual and health state, independence level, social relationship with the environment and others are influencedby the quality of life[14]. Quality of life has also been defined "as the satisfaction of an individual's values, goals and needs through the actualization of their abilities or lifestyle" [15].

Quality of life is assessed with the help of both objective and subjective indicators. In the quality of life research, one often distinguishes between the subjective and objective quality of life. Subjective quality of life is about feeling good and being satisfied with things in general. Objective quality of life is about fulfilling the society and cultural demands for material wealth, social status and physical well-being [16].

According to Ferrell, quality of life is one's well-being covering four areas, namely physical, mental, social and spiritual well-being [17]. Quality of life and well-being are practically interchangeable concepts but may be distinguished by the manner they are measured [18].

In this paper quality of life refersto the World Health Organization (WHO) definition [19] in the WHO Quality of Life-BREFF (WHOQOL-BREFF)as an individual's perception of their position and life in the context of culture and value systems associated with staying connected with the goals, expectations, standards and concerns. It covers physical health, psychological state, level of independence, social relationships, personal beliefs and relationship with the environment. The quality of life is not just simply related to health, lifestyle, life satisfaction, mental state and well-being, but is also related to the perception of the individual assessment of the level of mental health, the psychosocial and other aspects of life. The quality of life also includes physical and mental health and social well-being.

\section{THEORY}

The theory which will be discussed and is appropriate to the study of stress, anxiety, depression and quality of life is the stress life event theory, Freud's anxiety theory, Beck's cognitive theory of depression and the quality of life conceptual model.

\section{A. The Stressful Life Events Theory}

The Theory of Stressful Live Events was presented by Holmes and Rahe[20], and, Holmes and Matsu[21]. They agree with the opinion that the occurrence of specific eventsin life can have an impact on individual physical and mental self. Their research aims to formulate specific events in life that cause stress. According to this theory, stress appears to be based on the individual's experienced incidents where the incident raises coping behavior and adaptive responses. According to this theory, stress stems from life experience which in turn affects and change someone's life. This reflectnegative pressure that can affect the daily life journey.

\section{B. Freud's Anxiety Theory}

According to Freud in Strongman [22], anxiety is caused by threats or harassment individuals received. Anxiety is part 
of the natural instinct for self-safety stemming from emotional shock and fear of castration. Concerns create a sense of panic. Reality due to concerns result in bitter experience that the perception of the environment poses a threat in dealing with the fear of an environmental condition. This effect is sometimes able to affect up to a lifetime. Things that can inspire fear and stress to individuals will cause concerns in them to deal with the situation [23].

\section{Beck's Cognitive Theory of Depression}

Stress and anxiety experienced by the victims can finally create the symptoms of depression. According to Beck [24], depression is due to the attitude and mindset of private individuals and the symptoms showing signs of depression are a result of nonpeaceful thoughts. Those who are depressed are more likely to perceive their future experience as an understanding of the personal and impersonal factors. Cognitive structure between the input stimulus and response personality of the beliefs and assumptions relate to an object, event or environment. They also consider the future of their experience as negative and unrealistic. Depressed attitude is likely to be long-lasting and permanent if not controlled. They are also in a state of worry and concern. This theory describes the three negative thinking: man, of himself, the world and the future as he thinks. Negative thoughts of oneself are how individuals will see themselves in a negative frame of thought; thinking of oneself as inadequate and worthless. This condition will cause the individual to express himself or herself physically, mentally, and morally, and will further push himself or herself out of any activity.

\section{The Quality of Life Conceptual Model}

Perceived quality of life is closely related to psychological factors. Negative characteristics such as stress, anxiety and depression can affect the quality of life of victims. According to the quality of life model built by Zhan [25],the quality of life is defined as a life experience to identify and satisfy nature. The quality of life is affected by a person's background, health, and the situation. Symptoms of stress, change and adaptation functionality are considered as a medium of communication.

\section{INTEGRATED MODEL}

Fig. 1 shows how each theory integrates with each other. Through the model, it can be seen how floods become a trigger to stress experienced by the flood victims in Malaysia. The stressful life events theory states that stress emerges as a result of events experienced by individuals. Incidents result in a change which occur in the lives of the victims. Other theories integrated are the Freud's anxiety theory and the cognitive theory of depression in which reality concerns arising from bitter experience result in the perception that the environment poses a threat in dealing with the fear of anenvironmental condition, while depression emerges as a result of nonpeaceful thoughts. Those who suffer from depression have a negative perception of themselves. Beck's cognitive theory of depression integrates with the conceptual model of the quality of life of negativecharacteristics that can affect the quality of life enjoyed by the flood victims in Malaysia.

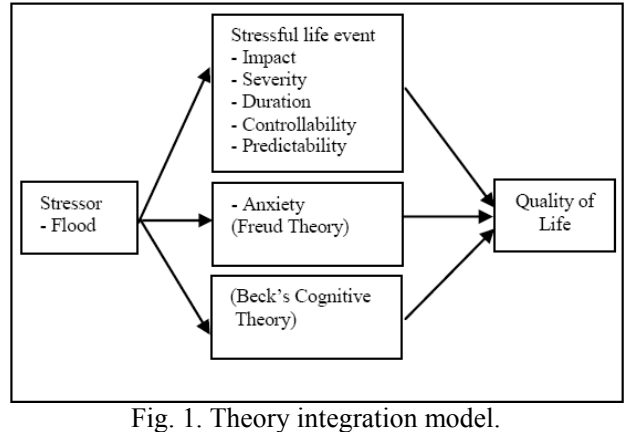

\section{DISCUSSION}

Floodsin Malaysia have caused a change in the lives of those affected. These changes sometimes provide pressure to the flood victims in their daily life. The relationship between experienced events and stress affect the victims indirectly. Pressure can affect the flood victims'quality of life. Despite this,sustained pressure varies with individuals. According to Ralf and Ute [26], although the flood disaster can be predicted and detected several days before the incident, it still givesshock and pressure to the flood victims, and this is considered as a perception of control (perceived controllability). Perception of control is considered to be one-dimensional in categorizingstressful life events. This disaster could provide pressure and alter the function of the victim's daily routines. For children,this disaster affects their daily routine and can cause negative effects if the routine is disrupted [27]. Flood victims also have thepossibilitiesof dealing with the stress response and ongoing trauma [28].

Some flood victims in Malaysia may experience anxiety every time there is heavy rain. This is due to the experience of the past, that heavy rain has resulted in flooding which destroyed crops and livestock, damage to property, loss of a financial equity and also resulted in the loss of life of family members. Their daily lives are always in a state of alert. Therefore, they are worried of repeated flooding [2]. The level of concern over the possibility of floods is experienced by those with lower incomes [29]. Anxiety and depression among victims are related to losses in the event of flooding and previous studies showed that if the aid in terms of counseling and social support aregiven several months after the incident, fear is reduced among the victims [30].

There are several limitations of human perception of risks related to the psychological mechanisms. Floods can cause unpleasant feelings of anxiety and lack of sense of security. For this reason every individual's emotional and psychological characteristics affect their perception. This can lead to an effect known as cognitive dissonance where one is confronted with information that affects the integrity of their beliefs about the world and cause internal tension.

Persistent concerns among the flood victims in Malaysia will lead to depressive behavior. Should any victims experience symptoms of depression, this will lead to negative stimuli in the self-improvement and consequently, the level of prosperity enjoyed is decreased [31]. Depression will cause a drop in the positive emotions of a person [32]. If someone is experiencing symptoms of depression, it will weaken and can lead to more serious mental health problems and other diseases. According to Beck, the negative thoughts 
experienced by a person as a result of negative assumptions on the environment held the loss of a loved one and the same scene over and over [33].

Flood not only affects the victims physically,but also from the security perspective as well as places of residence and family safety. These feelings, in turn, affect the quality of life and well-being enjoyed by flood victims in Malaysia. The quality of life degenerates if the victim is under pressure as a result of the incident. Different acceptance of these floods will cause different levels of the quality of life enjoyed. According to Diener [34], psychological well-being is dependent on the emotional enjoyment and fulfillment.

Sarason, James, and Judith [35] found that neither positive nor negative life changes were related to measures of depression and anxiety when only individuals with internal locus-of-control orientations were examined; that is, individuals who believe that they have control over their lives and unaffected by experienced life changes. Negative changes were significantly related to depression and anxiety only for individuals with external locus-of-control orientations. In this situation, negative events (and the persistent undesirable consequences of those events) may decrease self-regard in two related ways. Failures to control the occurrence of events or their undesirable consequences may decrease a sense of mastery or control over life [36]. The loss of valued social roles or inadequate performance in remaining roles may lower the value on individuals in their own and others' eyes [37], [38] and it will give rise to anxiety and depression. At the same time, it also affects the quality of life and well-being of the flood victims in Malaysia.

\section{CONCLUSION}

Flooding is one of the natural disasters that have an impact on victims in Malaysia. Natural disasters can lead to unpleasant feelingssuch as depression and anxiety. These factors affect the victims involved. This effect is known as cognitive dissonance where one is faced with situations that affect their faith in everyday life and cause a person to experience negative emotions. Stress, anxiety and depression experienced may involve the flood victims in Malaysia for a short period and sometimes it can be long-term. However, since the psychological factors are implicated both theoretically and empirically in the genesis of such behaviors[39], these actions will be included as mental-health outcome of interest.

The theorieshave allowed the researchers to examine the impacts of various types of flood experience toward the psychological well-being of the Malaysian flood victims. The more life changes individuals experience, regardless of the positive or negative aspects of change events, the more likely their coping or resistance resources will be faced with anxiety and depression.The crucial quality of life events in this formulation is believed to be undesirable; such events threaten the physical survival or emotional well-being of the Malaysian flood victims.

Utilising the said theories, a study is currently being conducted in Malaysia to examine the relationship between stress, anxiety and depression with quality of life among flood victims. It is hoped that the outcome of this study will further enhance the knowledge of these theories as an integrated model for flood victims' quality of life. Hopefully, the flood relief management programs and strategies maybe put forward and utilized by relevant authorities throughout Malaysia.

\section{REFERENCES}

[1] Malaysian Meteorology Department. (2011). Malaysia Climate. [Online]. Available: http:// www.met.gov.my.

[2] Department of Irrigation and Drainage Kubang Pasu. (2011). Report of Development and Implementation Status. [Online]. Available: http:// www.didkedah.gov.my/jpskppt/.

[3] W. T. Liu, X. Xie, and W. Tang, "Monsoon, orography and human influence on Asian rainfall," in Proc. First International Symposium on Cloud-Prone and Rainy Areas Remote Sensing, Hong Kong Chinese Univ. Press. 2005.

[4] M. K. Negara, Laporan Kesiapsiagaan Bencana Semasa Monsun Timur Laut, Malaysia, 2011.

[5] M. Sabitha, Tekanan Hidup Di Tempat KerjaSatu Pengenalan Pengurusanorganisasikerja,Sintok: Penerbit UUM.1998.

[6] C. E. Ferrans, "Development of a quality of life index for patients with cancer," OncologyNursing Forum, vol. 17, no. 3, pp. 15-19, 1990.

[7] D. B. Posen, "Stress management for patient and physician,"The Canadian of Continuing Medical Education, 1995.

[8] J. F. Thayer and R.D. Lane, "A model neurovisceral integration in emotion regulation and dysregulation," Journal of Affective Disorders, vol. 61, pp. 201-216, 2000.

[9] A. B. Amstadter, "Emotion regulation and anxiety disorders," Journal of Anxiety Disord, vol. 22, no. 2, pp 211-221, 2008.

[10] M. Stuart, "Understanding depression following a disaster," Cooperative Extension, College of Agriculture and Life Sciences, the University of Arizona, 2004.

[11] A. V. Horwitz, "How an age of anxiety became an age of depression," The Milbank Quaterly, vol. 88, no.1, pp 112-138, March 2010.

[12] S. H. Lovibond and P. F. Lovibond, Manual for the Depression Anxiety Stress Scales, 2nd. ed.,1995, Sydney: Psychology Foundation in M. Ramli, M. F. Ariff, and Z. Zaini, "Translation, validation and psychometric properties of Bahasa Malaysia version of the Depression Anxiety and Stress Scales (DASS)," ASEAN Journal of Psychiatry, 2007, vol. 8, no. 2, pp. 82-89, 2007.

[13] F. Oort, M. Visser, and M. Sprangers, "An application of structural equation modeling to detect response shifts and true change in quality of life data from cancer patients undergoing invasive surgery," Quality of Life Research, vol. 14, no. 3, pp. 599-609, 2005.

[14] D. Shin, "The concept of quality of life and the evaluation of development effort," in Comparative Politics, pp. 299-304, 1979.

[15] E. Emerson, "Evaluating the impact of deinstitutionalization on the lives of mentally retarded people," American Journal of Mental Deficiency, vol. 90, no. 3, pp. 277, 1985.

[16] D. Susnieneand A. Jurkauskas, The quality of life research centre 2005, "The concept of quality of life and happiness - Correlation and Differences,'InzinerineEkonomika-Engineering Economics, vol. 3, pp. 58-66, 2009

[17] B. Ferrell, "The impact of pain on quality of life: A decade of research," The Nursing Clinics of North America, 1995, vol. 30, no. 4, pp. 609.

[18] R. Zaimah, M. S. Sarmila, A. M. Azima, S. Suhana, M. Y. Hussain, and N. Lyndon, "KualitiHidupdankesejahteraanbelia: kajiankeataspekerja sector awam Malaysia," Malaysia Journal of Society and Space, vol. 8, Issue 6, pp. 150-156, 2012.

[19] World Health Organization. (1996). WHOQOL-BREF: Introduction, Administration, Scoring and Generic Version of the Assessment. [Online].

Available: http://www.who.int/mental_health/media/en/76.pdf.

[20] T. H. Holmes and R. H. Rahe, "The social adjustment rating scale," Journal of Psychosomatic Research, vol. 11, pp. 213-218, 1967.

[21] T. H. Holmesand M. Masuda, "Life change and illness susceptibility, Separation and depression," American Association for advancement of science, 1973, pp. 50-55

[22] K. T. Strongman, "Theory of anxiety," New Zealand Journal of Psychology, vol.24, no. 2, pp. 4-10, 1995.

[23] S. H. Calvin, A Primer of Freudian Psychology: A Mentor Book, Pennsylvania State University: New American Library, 1979.

[24] A. T. Beck, Depression: Clinical, Experimental, and Theoretical Aspects, New York: Harper \& Row, 1967.

[25] L. Zhan, "Quality of life: Conceptual and measure issues," Journal of Advance Nursing, vol. 17, pp. 795-800, 1992.

[26] S. Ralf and S. Ute, "The role of stressful life events," Health Psychology, vol. 9, pp. 1-32, 2001. 
[27] R. Pynoos, A. Steinberg, and R. Raith, "A development model of posttraumatic stress disorder in children and adolescents," in D. J. Cohen and D. Cicchetti, eds., Manual of Developmental Psychopathology, Risk, Disorder, and Adaptation, New York: John Wiley and Sons, vol. 2, pp. 72-95, 1995.

[28] A. La Greca, W. K. Silverman, E. M. Vernberg, and M. J Prinstein, "Symptoms ofposttraumatic stress in children after hurricane andrew: A prospective study,"Journal of Consulting and Clinical Psychology, vol. 64, no. 4, pp. 712-723, 1996.

[29] G. Shah, "Social work in disaster," Indian Journal of Social Work, vol. 45, pp. 463-475, 1985.

[30] M. G. Elizabeth, W. Karen, and J. S. Samuel, "Natural disaster and depression: A prospective investigation of reactions to the 1993 midwest floods," American Journal of Community Psychology, vol. 28 no. 4, 2000.

[31] M. R. Carien, L. U. Heather, J. Tom, E. T. Marchell, J. F. Corrina, A. J. Cory, S. S. Hillary, L. A. Andrew, and J. D. Richard, "Individual differences in amygdala and ventromedial prefrontal cortex activity are associated with evaluation speed and psychological well-being," Journal of CognitiveNeuroscience, vol. 19, no. 2, pp. 237-248, 2007.

[32] D. Watson, L. A. Clark, and G. Carey, "Positive and negative affectivity and their relation toanxiety and depressive disorders," Journal of Abnorm, Psychol, vol. 97, pp. 346-353, 1988.

[33] N. L. Lubis, Depresi, Tinjauan Psikologis Jakarta: Kencana Prenada Media Group, 2009.

[34] E. Diener, E. M. Suh, R. E. Lucas, and H. L. Smith, "Subjective well-being," Psychol Bull,vol. 125, pp. 276-302, 1999.

[35] I. G. Sarason, H. J. James, and M. S. Judith, "Assessing the impact of life changes: Development of the life experience survey," Journal of Consulting and Clinical Psychology, vol. 46, pp. 932-946, 1978.

[36] L.Y. Abramson, E. P. Martin, Seligman, and D. T. John, "Learned helpness in humans: Critique and reformulation," Journal of Abnormal Psychology, vol. 87, pp. 49-74, 1978.

[37] H. B. Kaplan, Deviant Behavior in Defense of Self, New York: Academic Press, 1980.

[38] H. B. Kaplan, Psychosocial Stress: Trend in Theory and Research, New York: Academic Press, 1980.

[39] Y. Badi'ah, B. Sulaiman, H. Rohaya, M. Z. MohdZaidi, and R. Rohailina, "Pychological effect on flood victims in Johore State," Community Health Journal, vol. 15, pp. 79-87, 2010.

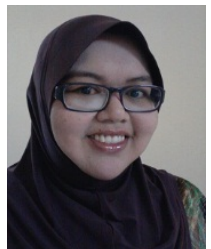

Johana Johari graduatedwith a bachelor of international affairs management from Universiti Utara Malaysia, Sintok, Kedah, in 2002. The author is currently pursuing her Master's at the same university and the major field of her study is psychology.

She is currently a Research assistant attached to the School of Social Development, College of Arts and Sciences, Universiti Utara Malaysia.

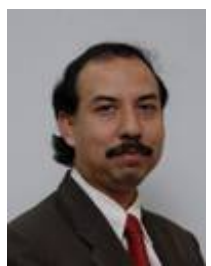

Najib Ahmad Marzuki is a professor at the Department of Psychology \& Social Work, School of Social Development, College of Arts and Sciences, Universiti Utara Malaysia. He received his B.A. (Hons) in Psychology from UniversitiKebangsaan Malaysia, Master in Industrial and Organizational Psychology from the University of New Haven, Connecticut, USA, in 1989 and Ph.D. in Psychology from the University of Nottingham, United Kingdom.

The author is currently a Registered Qualified Test User (RQTU) in Occupational Testing from the Psychological Testing Centre, British Psychological Society, United Kingdom.

Professor Dr. Najib Ahmad Marzuki has served Universiti Utara Malaysia for more than 23 years. Currently, he is the Dean for the School of Social Development, College of Arts and Sciences, Universiti Utara Malaysia. He has published articles in both local and international journals and presented papers in international conferences. He has also been appointed as the external examiner for Ph.D. and Master's theses in various universities. His area of specialization and research interests include general psychology, industrial/organizational psychology, personnel selection, selection interview, emotional intelligence, motivation, stress and job satisfaction.

$\mathrm{He}$ is a member of several professional associations (local and international) including the Malaysian Psychological Association, American Psychological Association and the International Association of Applied Psychology. 